\title{
Interaction of coeval felsic and mafic magmas from the Kanker granite, Pithora region, Bastar Craton, Central India
}

\author{
R Elangovan ${ }^{1}$, Kumar Krishna ${ }^{1}$, Neeraj Vishwakarma ${ }^{2}$, K R Hari $^{3}$ and \\ M RAM MOHAN ${ }^{1, *}$ \\ ${ }^{1}$ CSIR-National Geophysical Research Institute, Hyderabad 500 00\%, India. \\ ${ }^{2}$ Department of Applied Geology, National Institute of Technology, Raipur 492 010, India. \\ ${ }^{3}$ Department of Geology and Water Resources Management, Pt. Ravishankar Shukla University, \\ Raipur 492 010, India. \\ *Corresponding author.e-mail: rammohan@ngri.res.in
}

MS received 2 January 2017; revised 18 April 2017; accepted 20 April 2017; published online 5 October 2017

Field and petrographic studies are carried out to characterize the interactions of mafic and felsic magmas from Pithora region of the northeastern part of the Bastar Craton. The MMEs, syn-plutonic mafic dykes, cuspate contacts, magmatic flow textures, mingling and hybridization suggest the coeval emplacement of end member magmas. Petrographic evidences such as disequilibrium assemblages, resorption textures, quartz ocelli, rapakivi and poikilitic textures suggest magma mingling and mixing phenomena. Such features of mingling and mixing of the felsic and mafic magma manifest the magma chamber processes. Introduction of mafic magmas into the felsic magmas before initiation of crystallization of the latter, results in hybrid magmas under the influence of thermal and chemical exchange. The mechanical exchange occurs between the coexisting magmas due to viscosity contrast, if the mafic magma enters slightly later into the magma chamber, then the felsic magma starts to crystallize. Blobs of mafic magma form as MMEs in the felsic magma and they scatter throughout the pluton due to convection. At a later stage, if mafic magma enters the system after partial crystallization of felsic phase, mechanical interaction between the magmas leads to the formation of fragmented dyke or syn-plutonic mafic dyke. All these features are well-documented in the study area. Field and petrographic evidences suggest that the textural variations from Pithora region of Bastar Craton are the outcome of magma mingling, mixing and hybridization processes.

Keywords. Kanker granite; mafic microgranular enclaves (MMEs); syn-plutonic mafic dyke; magma mixing and mingling; Bastar Craton.

\section{Introduction}

Numerous examples of magma mixing and mingling are documented in exhumed magma chambers through field, petrographic and geochemical studies on the mafic microgranular enclaves, syn-plutonic mafic dykes, hybrid enclaves and host granitoids (Hibbard 1981; Frost and Mahood 1987; Barbarin 2005; Kumar 2010; Perugini and Poli 2012; Jayananda et al. 2014). Such studies are confined mostly to calc-alkaline plutons of the Phanerozoic (Arvin et al. 2004; Kumar 
2010; Kumar et al. 2016), but similar studies that document magma chamber processes from Indian territory are very limited (Kumar et al. 2005; Kumar and Rino 2006; Jayananda et al. 2009, 2014; Prabhakar et al. 2009). Magma mixing process involves mixing and mingling of two compositionally different magmas to form a hybrid magma. The composition of the hybrid magma lies somewhere between the two end members of mixing magmas. Two types of interaction, namely the chemical interaction and physical interaction occur during the magma mixing process (Barbarin and Didier 1992). During mixing process, chemical interaction occurs between the two magmas and produces compositionally homogeneous hybrid rocks, wherein the identities of original magmas are disappeared. In contrast, the mingling process leads to mechanical interaction, wherein the primary magmas retain their identity, thus these magmas are compositionally heterogeneous. Petrogenetically, granitoids form due to fractional crystallization and assimilation/partial melting and magma mixing processes (Martin et al. 2009; Moyen et al. 2010; Moyen 2011). Magma mixing processes play a very important role in the formation of compositionally intermediate granitoids such as quartz monzodiorite, monzodiorite, diorite and andesite.

In this study, we document the field and petrographic features of the MMEs, syn-plutonic dykes, hybrid enclaves and host plutonic rocks of Pithora region in the northeastern part of the Bastar Craton to characterize the interaction between the coexisting felsic and mafic magmas, to understand the emplacement mechanism of hybrid magmas, and the role of magma chamber processes for the formation of MMEs and their host granites.

\section{Geological setting and previous work}

The Bastar Craton (BC) (figure 1a) also known as Bastar-Bhandara Craton, is one of the major cratons in the Indian Shield. This craton is bounded by Central Indian Tectonic Zone in the north, Mahanadi graben to the northeast, Deccan trap to the west, Eastern Ghats mobile belt to the east and Godavari graben covers the southern margin (figure 1a). The craton is essentially composed of orthogneisses with enclaves of amphibolites, vestiges of banded TTG gneisses of Mesoarchean age that are extensively exposed in the south and western part of the craton. TTG gneisses, rafts of sediments of quartzite carbonate-pelite facies, along with mafic-ultramafic rocks and minor BIF are together called as supracrustal rocks. These rocks occur as scattered enclaves and narrow belts within the Archaean gneisses and granites, collectively called as Sukma Group in the south and Amagaon Group in the north, followed by Bhopalapatnam and Kondagaon granulite belts. The successive metasedimentary units of quartzite schist, metabasalts, andalusite schist and conglomerate rocks form the Bengpal Group. Narrow N-S trending rift and its intra-cratonic orogen, that is made of several cycles of sedimentation and volcanics rocks are called as Kotri-Dongargarh Orogeny. Biladila Group forms basinal succession and southern part of Kotri-Dongargarh Orogen; it comprises basal quartzite, phyllite, and BIFs. The next succession of felsic and mafic volcanics with pyroclastics, basal conglomerate and quartzite are called as Nandgaon Group and these are new cycle of volcanics after the sedimentation of a Bailadila Group in the Kotri-Dongargarh Orogeny. Rhyolite of a Bailadila Group yields $\mathrm{Rb}-\mathrm{Sr}$ whole rock isochron age of $\sim 2300 \mathrm{Ma}$ (Ramakrishnan and Vaidyanathan 2008). Greenstone belt of Bagmara, Arjuni and Bilari Formation forms Sonakhan Group in rest of the Bastar Craton. Large bodies of granites, mainly formed during the Neoarchean/Paleoproterozoic era, which intrude the gneisses and supracrustal rocks, are well-known as Dongargarh, Malanj khand and Kanker granites following locality names. The Nandgaon Group is unconformably overlain by basalts alternating with sedimentary units referred to as Khairagarh Group in the Kotri-Dongargarh Orogeny.

Geology of the southern part of Bastar Craton was detailed by many workers (Crookshank 1938; Ghosh 1941; Bandyopadhyay et al. 1994; Chatterjee 1970; Mishra et al. 1988; Ramachandra et al. 2001). The trondhjemitic granitic gneisses occurring as enclaves and the host granitoids that contain the gneisses yielded $\mathrm{U}-\mathrm{Pb}$ zircon ages of 3.5 and $2.4 \mathrm{Ga}$, respectively (Sarkar et al. 1993). An age of $3.0 \mathrm{Ga}$ has been reported for the gneisses of granitic composition (Sarkar et al. 1990). The tonalite gneiss from the central part of Bastar Craton yielded U-Pb zircon ages of 3.56 Ga (Ghosh 2004). The field evidences for mingling and mixing of felsic and mafic magmas were reported from the Malanjkhand granite (Kumar et al. 2004). Malanjkhand granite is relatively wellstudied, due to its proximity with polymetallic 


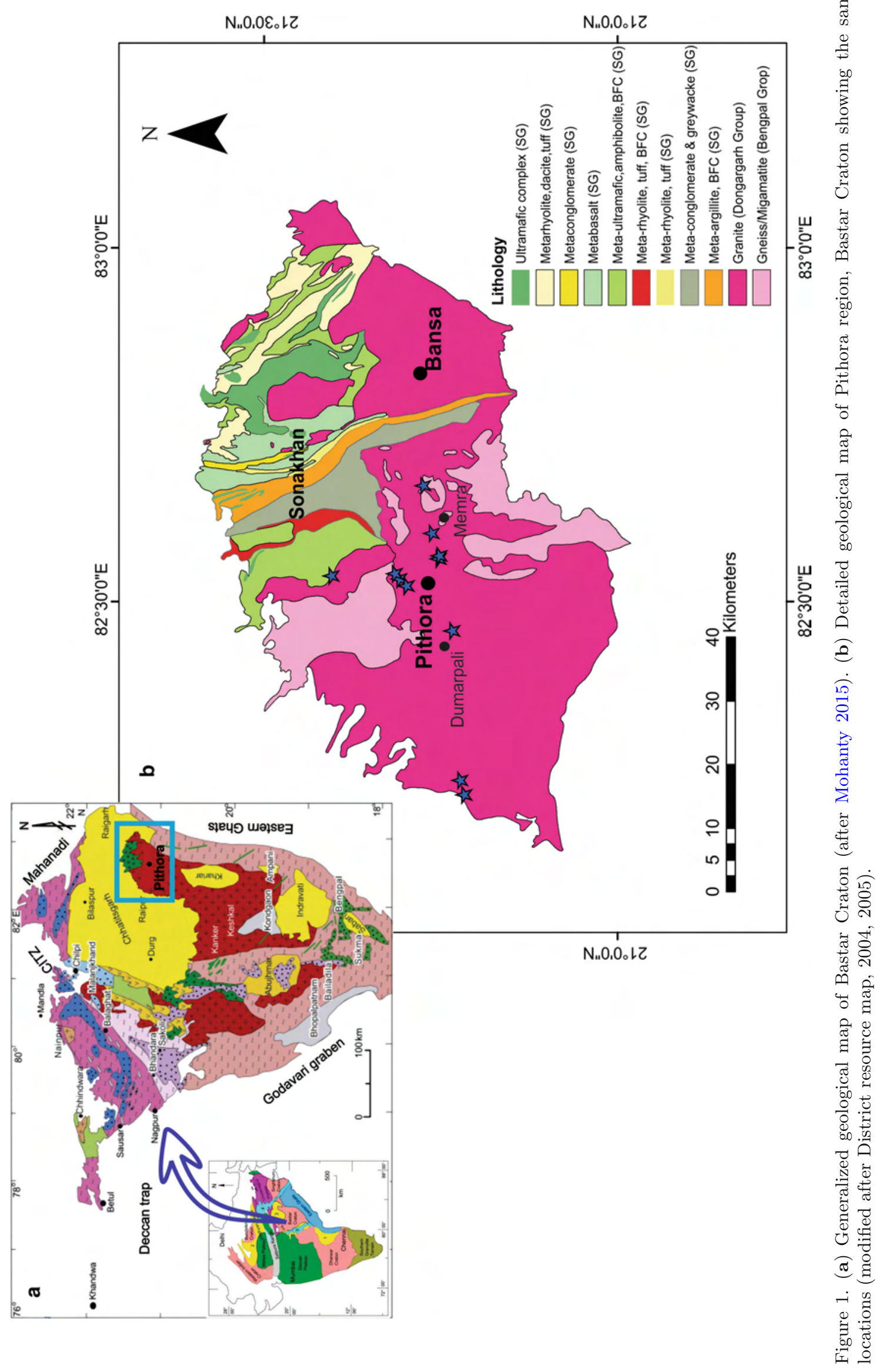



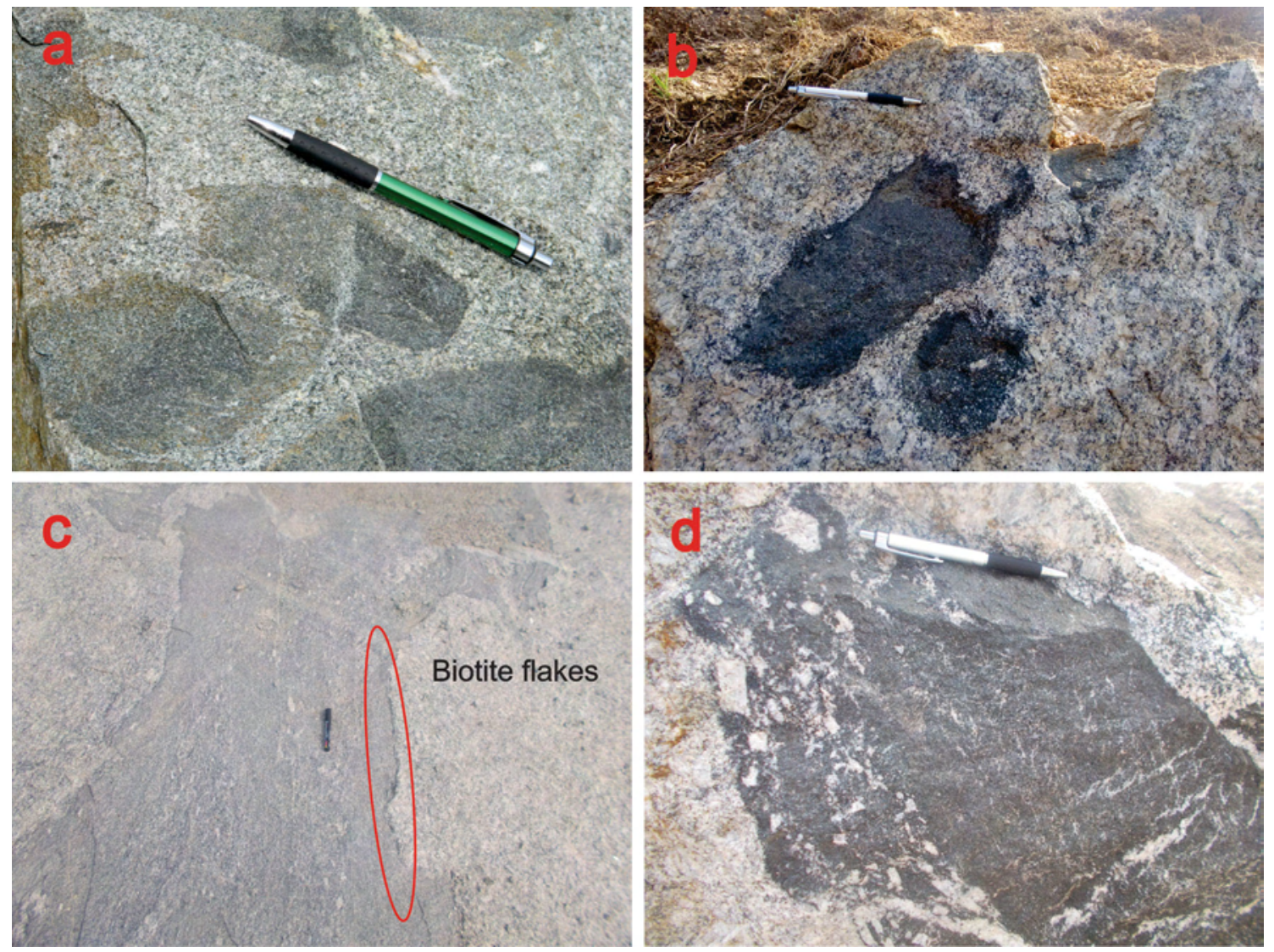

Figure 2. (a) Ellipsoidal or sub-rounded MMEs are enclosed within the host granite in northern part of Pithora region; (b) Small clot of MMEs are mechanically getting diluted and early formed K-feldspar phenocryst intruding into the MMEs; (c) Biotite flakes formed between mesocratic fine-grained syn-plutonic mafic dyke and the coarse-grained porphyritic granite; (d) The early formed K-feldspars intruding into the MME from the crystallized host granite.

mineralization. The $\mathrm{Rb}-\mathrm{Sr}, \mathrm{Sm}-\mathrm{Nd}$ and $\mathrm{Pb}-\mathrm{Pb}$ whole rock isochron studies on the Dongargarh granite (Sarkar et al. 1981; Pandey et al. 1993) yielded Paleoproterozoic ages (2270土90; $2361 \pm 114 ; 2462 \pm 22 \mathrm{Ma})$, while the Neoarchean age $(2506 \pm 50 \mathrm{Ma})$ was obtained by $\mathrm{U}-\mathrm{Pb}$ zircon method (Manikyamba et al. 2016). Comparison in terms of the petrogenesis and tectonics of Malanjkhand and Dongargarh granitoids was attempted (Pandit and Panigrahi 2012); however, not much information is available for Kanker granites. The bimodal volcanism has been reported from the Kotri-Dongargarh belt, the $\mathrm{U}-\mathrm{Pb}$ zircon data of these mafic and felsic volcanics yielded the emplacement ages at $2471 \pm 7$ and $2479 \pm 13 \mathrm{Ma}$, respectively (Manikyamba et al. 2016).

Kanker granites cover an area of $1000 \mathrm{~km}^{2}$. These granites are unconformably overlain by the Chhattisgarh basin and forms the basement for Purana basins in Bastar Craton. The study area (figure 1b) at Pithora region forms part of the Kanker granites, located in eastern side of the
Bastar Craton. The Pithora granites have intrusive relationship with the Sonakhan greenstone belt. In this study, we discuss the field and petrographic characteristics of MMEs and syn-plutonic mafic dykes and their relationship with host granites to understand the magma chamber processes that involved in the petrogenesis of Kanker granites of Pithora region.

\section{Field relationships and petrography}

\subsection{Granite}

K-feldspar rich, coarse-grained pink granite, medium-grained grey granite and very-coarse grained porphyritic granite are the three types of granites observed in the study area. Migmatitic gneiss was observed in the Memra village (figure $1 b)$. The granites are medium to coarsegrained, equi-granular to porphyritic in nature. 

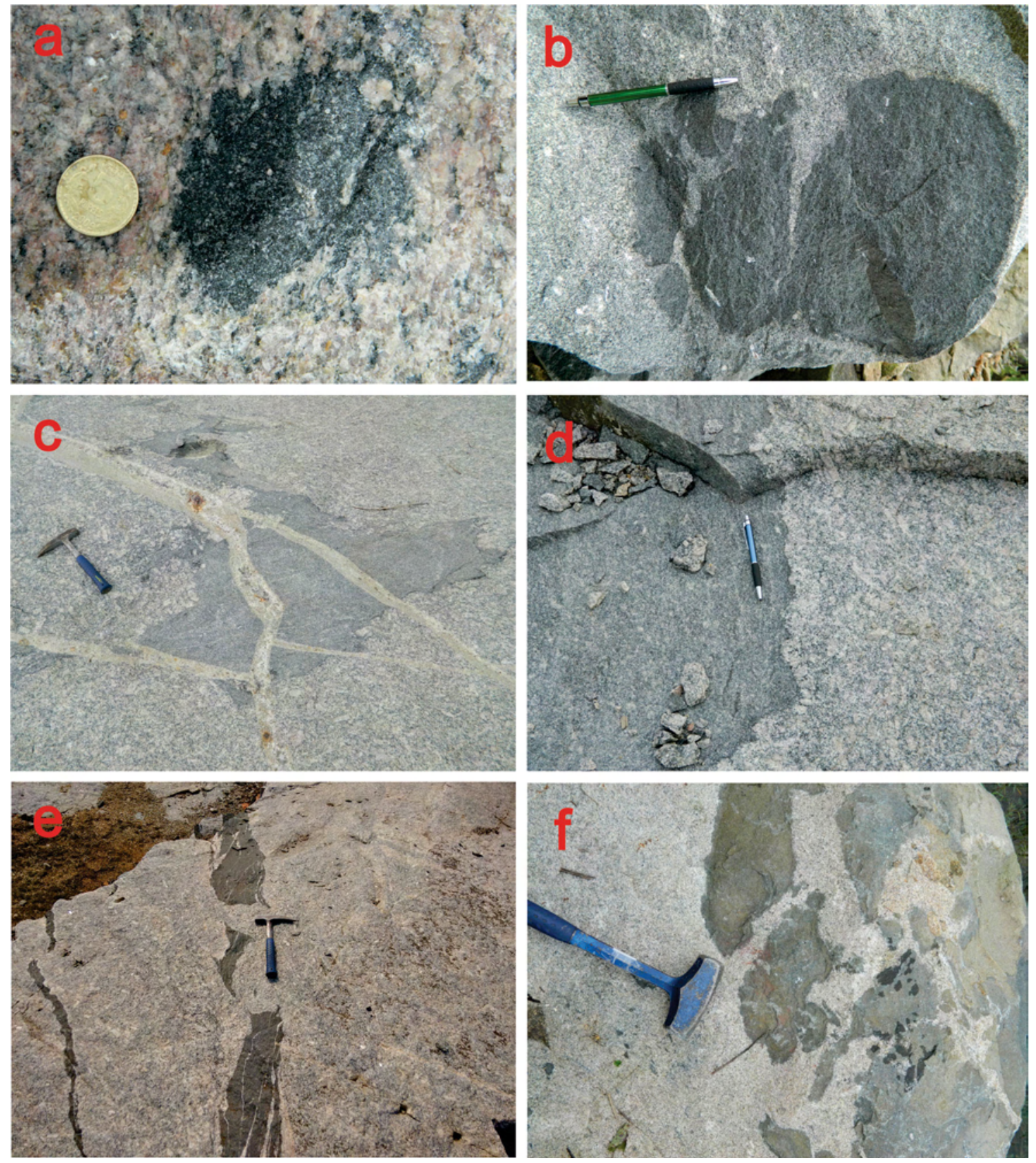

Figure 3. (a) Ellipsoidal shaped MME exhibiting partially diffused contact with the host granite; (b) Fine-grained sub-rounded MMEs disintegrating due to the intrusion of crystallizing felsic magma; (c) Polygonal shaped MMEs within the porphyritic granite, and the later formed aplitic vein intruding into the MME as well as the host porphyritic granite; (d) Mesocratic MMEs showing crenulated contact with the host porphyritic granite, and the K-feldspar phenocrysts of the host granite are concentrated around the MMEs; (e) Fragmented syn-plutonic mafic dyke intruding into coarse-grained porphyritic granite; (f) Numerous elliptical disrupted syn-plutonic mafic dykes having cuspate and lobate contact with the host granite.

The K-feldspar phenocrysts (figure 10) are $2-5$ $\mathrm{cm}$ in size and epidote veins (figure 10b) are intruding into the granite and MMEs. Kanker granites are primarily made of quartz, plagioclase, K-feldspar, biotite and hornblende. Zircon, apatite, titanite and opaques are the accessory minerals.

\subsection{MME and syn-plutonic mafic dyke}

The outcome of magma mixing and mingling processes can be divided into three megascopic features, and such features have been recognized at numerous outcrops in Pithora region. They are: (1) mafic magmatic enclaves (MMEs), (2) 

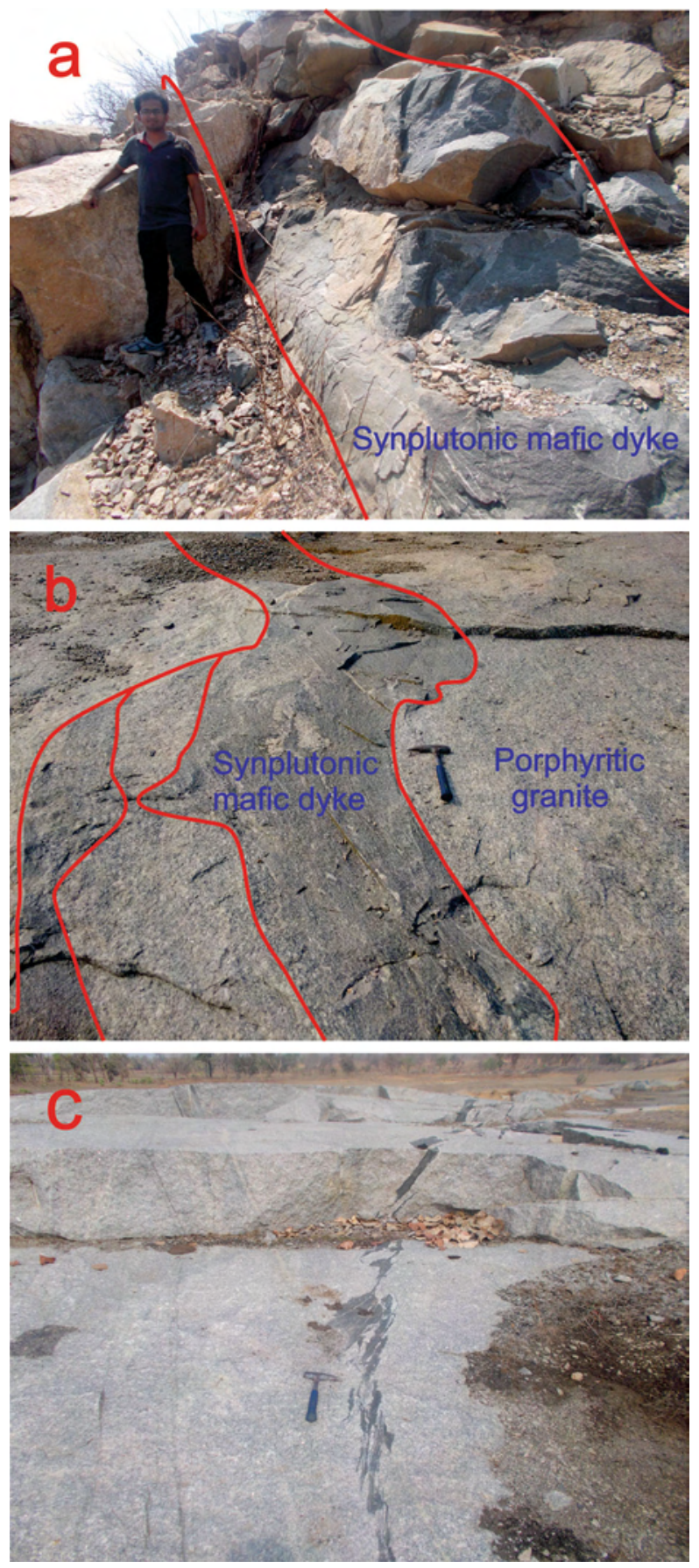

Figure 4. (a) Syn-plutonic mafic dyke ( $1.5 \mathrm{~m}$ width) intruding into the medium-grained granite in northern part of Pithora region; (b) Syn-plutonic mafic dyke intrusion into crystallized host. During the intrusion, partially crystallized host felsic magma also got intruded into the syn-plutonic mafic dyke in the Sindhupali area of Pithora region; (c) Melanocratic discontinuous syn-plutonic mafic dyke intruding into the porphyritic granite.

syn-plutonic mafic dykes and (3) flow structures. MMEs are scattered over the calc-alkaline granites with different shapes. They are fine grained, melano- to mesocratic with size ranging from 5 to $50 \mathrm{~cm}$. The mesocratic MMEs are ellipsoidal to sub-rounded, displaying sharp contact with the host rock (figure 2a). Fine-grained ellipsoidal MMEs (figure 2b) are melanocratic, having diffused contact with the host porphyritic granite. Mesocratic syn-plutonic mafic dyke (figure 2c) is intruding into porphyritic granite along with schlieren (biotite flakes). These schlieren occur along the contact between the syn-plutonic mafic dyke and the host granite. K-feldspar phenocrysts of the host granite occur as xenocrysts in MMEs (figure 2d). Ellipsoidal MME shows partially diffused contact with the coarse-grained pink granite (figure 3a). Fine-grained sub-rounded MME (figure $3 \mathrm{~b}$ ) is disintegrated due to the intrusion of crystallizing felsic host. In Dumarpali region, very coarse-grained porphyritic grey granite with irregular shaped MME are observed (figure 3c). Aplitic veins are seen intruding into the granite and MME, and could represent the latest phase in the region. Mesocratic MME (figure 3d) have crenulated contact with the porphyritic granite and the phenocrysts are concentrated around the MME. Continuous and discontinuous syn-plutonic mafic dykes are observed in and around the Pithora region. Continuous dykes are found infrequently (figure 4a), measuring $1.5-2 \mathrm{~m}$ in width and 10-15 $\mathrm{m}$ in length. Syn-plutonic mafic dyke (figure $4 \mathrm{~b}$ ) is observed near Dumarpali village, to the SW of Pithora, which intrudes into the porphyritic grey granite. Numerous melanocratic ellipsoidal shaped, disrupted syn-plutonic mafic dykes (figure 3f) having cuspate to lobate contact with the host granite are observed. Disrupted linear synplutonic mafic dyke has intruded along the early fractures of the porphyritic granite (figures $3 \mathrm{e}$ and $4 \mathrm{c})$.

\subsection{Flow structures}

The slender-shaped enclaves (figure 5c) got diluted with host granite, occur in the tail region, exhibited as schlieren structure, having diffused contact with the host granite. These features are common in the southern part of Pithora region (figures $5 \mathrm{~d}$ and $6 \mathrm{~d}$ ). Numerous trails of oriented elliptical MMEs are delineating the mafic magmatic flow in the medium grained grey granite (figure 6a). Sub-rounded MMEs has tail structure, formed during the movement of mafic magma into the felsic magma (figure $6 \mathrm{~b}$ ), found in the northern part of the Pithora region. In the western part, linear synplutonic dykes having cuspate and lobate contact 

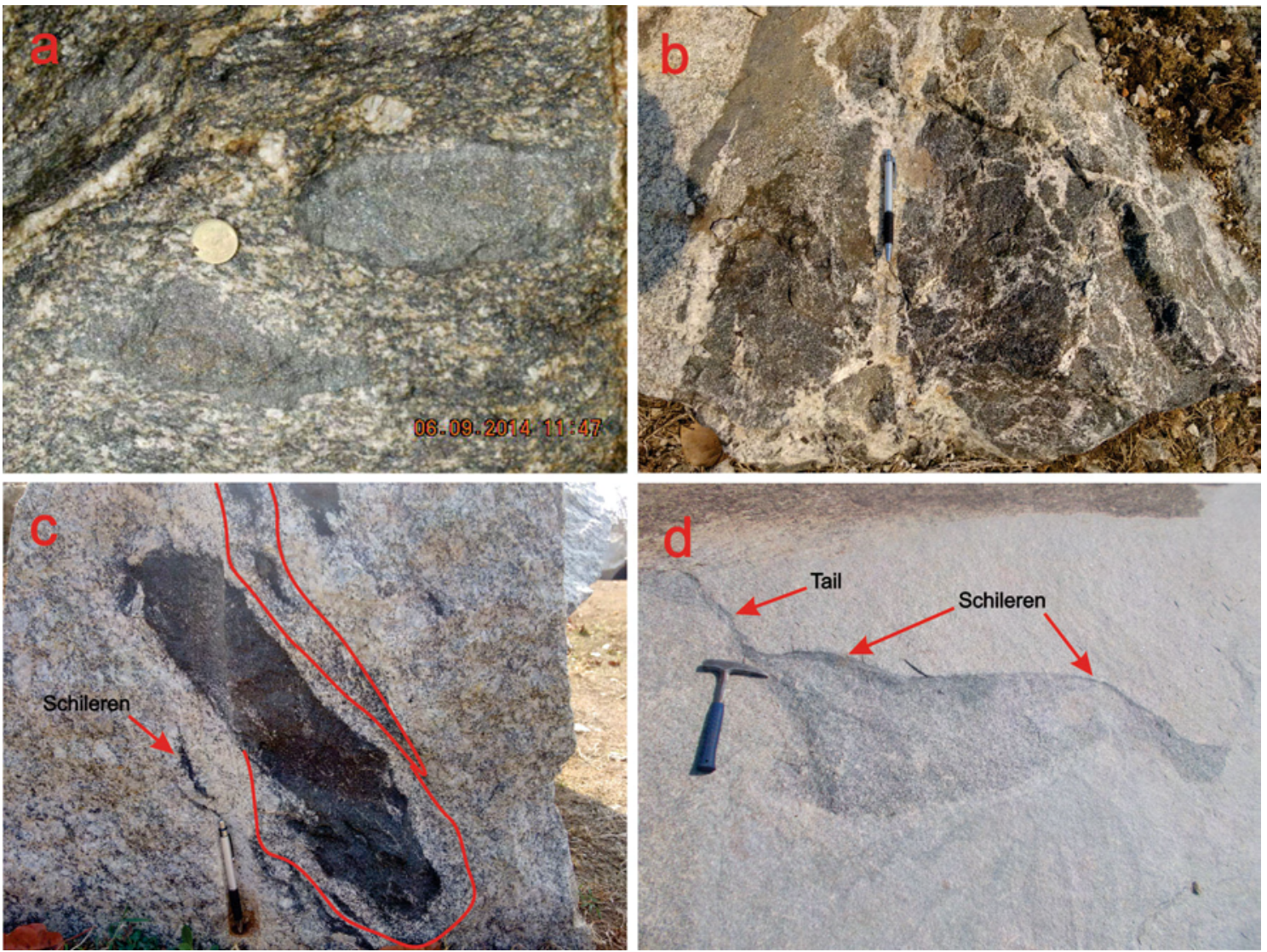

Figure 5. (a) Elliptical MME intruding into the hybrid zone along with mafic and felsic minerals (partially foliated); (b) Numerous hybrid enclaves are mechanically fragmented during the intrusion of host felsic magma; (c) Slender shaped enclaves are diluted at tail region, forming schlieren structure (Red-marked portion is diluted with crystallizing felsic magma); (d) MME mixed with host felsic magma to form hybridized enclave; during hybridization, schlieren are formed.

with the host porphyritic granites are observed (figure 6c).

\subsection{Petrography}

The petrographic features of granite, MMEs, and syn-plutonic mafic dyke have been studied. The host granite is characterized by medium to very coarse-grained, equigranular to porphyritic in nature. Major minerals are quartz, K-feldspar and plagioclase feldspar and accessory minerals are biotite, hornblende, titanite, apatite and zircon. Observed intergrowth textures are poikilitic, myrmekitic and perthite in the host granite. Micro-phenocryst of microcline shows poikilitic texture and it has inclusions of quartz and plagioclase (figure 7a) along with biotite altering into chlorite and the plagioclase feldspars are partially sericitized and saussuritized (figure 7b). Textures observed in MMEs and syn-plutonic mafic dykes are rapakivi, resorption, disequilibrium assemblage and poikilitic. Such textures along with crystal habits (acicular and needled) aids in understanding the interaction of coeval mafic and felsic magmas. MMEs and syn-plutonic mafic dykes are mostly fine to medium grained. Major minerals are hornblende, plagioclase, alkali feldspar, biotite and quartz. Accessory minerals include epidote, titanite, apatite and opaque. Needle-like biotites are partially oriented (figure 7c) and plagioclase feldspars are sericitized and saussuritized within the MMEs (figure 7d). The early formed alkali feldspar is mantled by plagioclase feldspar in the granitoids (figure 8a) and plagioclase feldspar shows that cellular texture due to the Ca-rich zone is sericitized along with the resorbed boundary (figure $8 \mathrm{~b}$ ). Ocelli texture is exhibited by quartz grains which are surrounded by bladed biotites in the host granitoids. Similarly, alkali feldspars are surrounded by hornblende in MME and syn-plutonic mafic dyke (figure $8 \mathrm{c}$ and d). Acicular apatites poikilitically enclosed in the alkali feldspar within the MMEs and syn-plutonic mafic dyke (figure 8e and 9a) are due to quenching of the mafic magma. Early formed microcline is enclosed by hornblende in syn-plutonic mafic dyke (figure 8f). The sudden cooling of the 

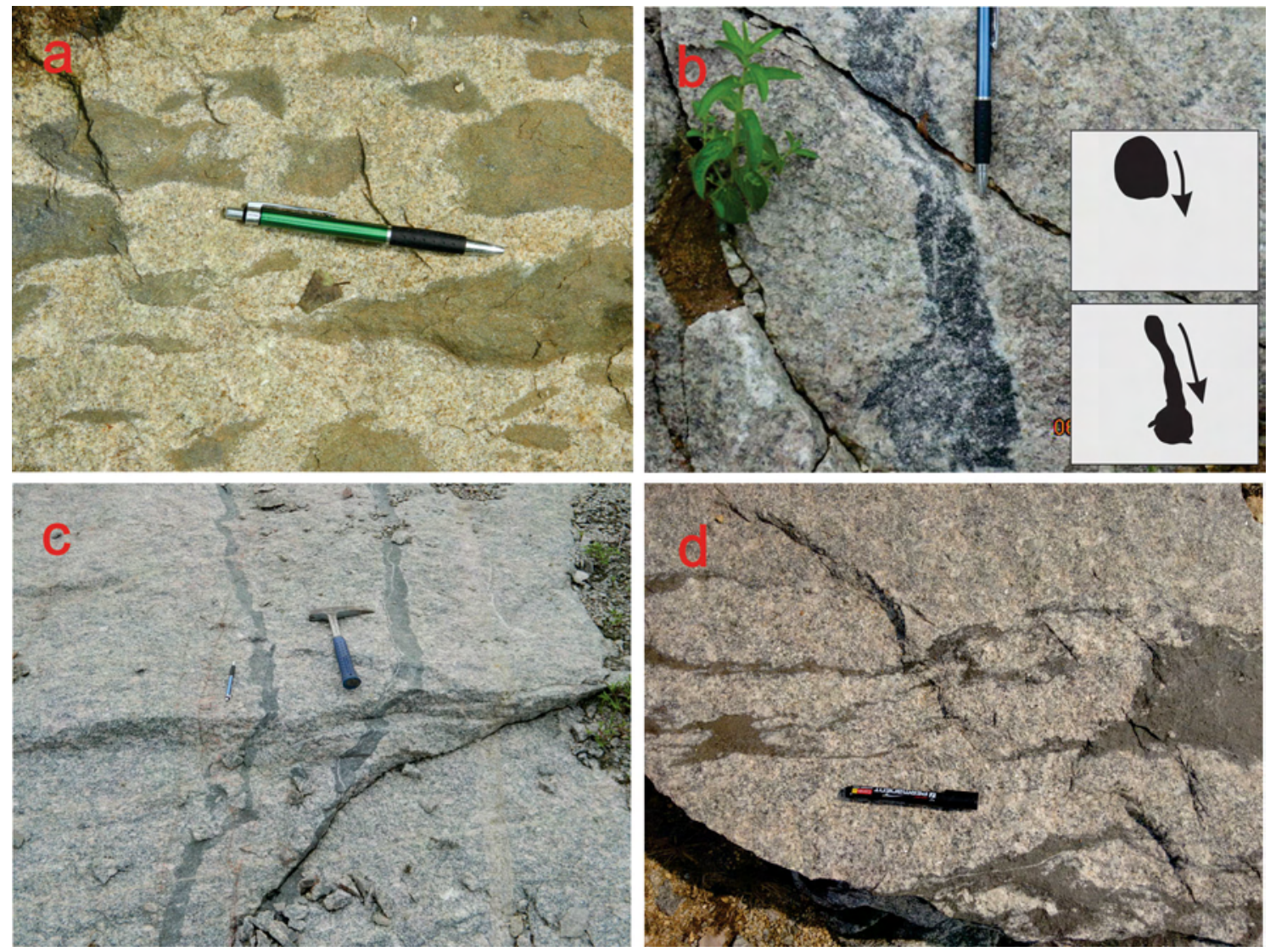

Figure 6. (a) Numerous trails of oriented elliptical MMEs delineate mafic magma flow; (b) Sub-rounded MMEs with tail structure defining the movement of mafic magma into the felsic magma and the cartoon diagram explains the movement of the enclave and the tail formation; (c) Syn-plutonic mafic linear dyke has lobate and cuspate contact with the host porphyritic granite; (d) Schlieren formed during the movement of disrupted syn-plutonic mafic dyke in the porphyritic granite.

injected magma led to low growth rate and high nucleation rate of the essential minerals, resulting in fine grained texture for syn-plutonic mafic dyke (figure 9c). Hornblende poikilitically encloses the alkali feldspar and plagioclase alters to sericite and epidote (figure 9b).

\section{Discussion}

\subsection{Coeval felsic and mafic magmas: Field and petrographic evidences}

Interaction of coeval felsic and mafic magmas can lead to mixing, mingling and chemical exchanges, depending on the viscosity and crystallinity of magma (Barbarin 2005). Evidence for such interactions are noted at megascopic level in Pithora region, in the form of hot mafic magma injecting into a relatively cold felsic host (figures 2 and 3 ). During such injection, due to thermal and rheological contrast, mica-rich schlieren has been formed along the margin of syn-plutonic mafic dyke (figure 2c). The observed lobate to crenulated and cuspate (figures 3d and 10a) contacts represent the existence of two liquids of different compositions within the magma chamber. The abundance of rounded to elongate MMEs suggests that both magmas co-existed, and mingling occurred at the site of emplacement prior to their crystallization (Vernon et al. 1988). In the Dumarpali region, K-feldspar phenocrysts are enclosed in MMEs as xenocrysts (figures 2d, 10a and b) and few are in contact with MMEs and also with the host (figures $3 \mathrm{~d}$ and 10a), indicating that the early formed phenocrysts are incorporated from the crystallizing host (Barbarin 1988). If the mafic magma intrudes when the felsic magma is crystallizing, the effective viscosity of the felsic magma would be significantly lower than the former. Such viscosity contrast results in the formation of MME blobs (Barbarin and Didier 1992). Mafic magmas when introduced at a later stage into a significantly crystallized 

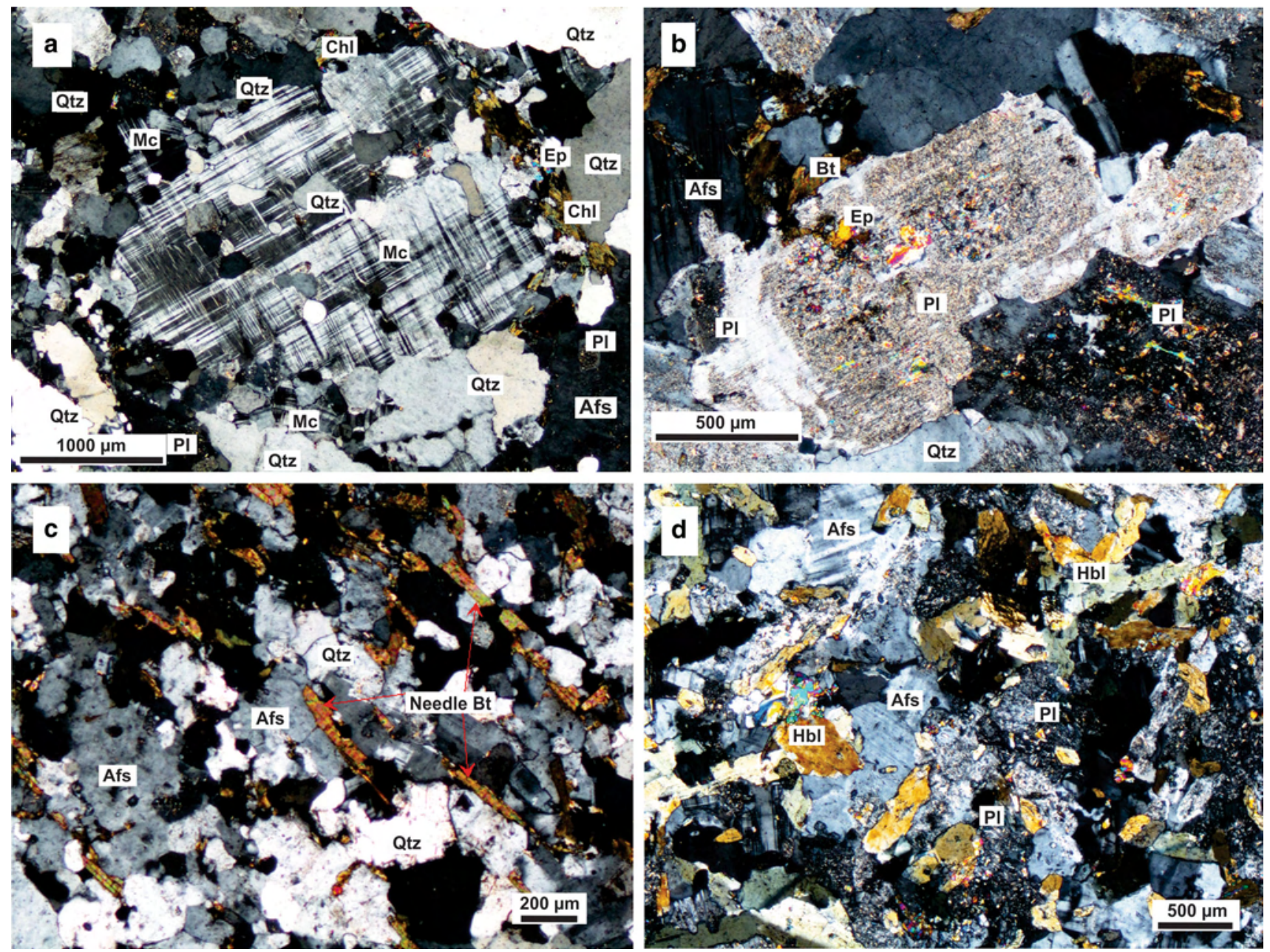

Figure 7. Petrographic features of the host granite and MME: (a) Microcline showing cross-hatched twinning poikilitically encloses quartz in the host granite; (b) Plagioclase feldspars showing initial stage of sericitization in the host granite; (c) Needle-like biotite grains oriented in a particular direction, due to the rapid cooling of intruded mafic magma into host felsic magma; (d) Hornblende encloses the early formed alkali feldspar and plagioclase are sericitized in the MMEs.

granitic rock, leads to the formation of continuous syn-plutonic mafic dyke (figure $4 \mathrm{a}$ and b) as described by Barbarin and Didier (1992). After the emplacement, dykes were linearly stretched or became discontinuous bodies (figure 4c) due to the influence of magma flow in the magma chamber. Syn-plutonic mafic dykes and host porphyritic granites are mixed by mechanical interaction (figure $4 \mathrm{~b}$ ), suggesting that both magmas are coeval in nature. Flow structures are an outcome of magmatic flow during the consolidation of magma in the magma chamber and are commonly referred to as schlieren structures (Didier and Barbarin 1991; Renjith et al. 2014). These structures are widely observed in the Kanker granites, often associated with MMEs and linear syn-plutonic dykes (figures 5c, d and 6). Tail structures (figures $5 \mathrm{~d}$ and $6 \mathrm{~b}$ ) are formed due to the movement of MMEs in crystallizing felsic host, an evidence for the magmatic flow during the consolidation of magma. After intrusion, syn-plutonic mafic dykes moved due to the influence of magma flow within the magma chamber resulting in schlieren structure (figure 6d). Chilled margin of the fine grained MMEs and syn-plutonic mafic dykes within host granite indicates that hot mafic magma was injected into the relatively cold crystallizing felsic magma (Kumar et al. 2004), and such features are observed at many places in the study area (figure 10b).

Petrographic evidences like ocellar quartz, crystal nucleation, dissolution, poikilitically enclosed alkali feldspar in hornblende, epitaxial crystallization, cellular zoning and resorbed surfaces illustrate magma mixing and mingling of mafic and felsic magmas. Mantling of plagioclase on K-feldspar showing cellular zoning and alteration (figure 11a), occurred due to thermal quenching during magma 

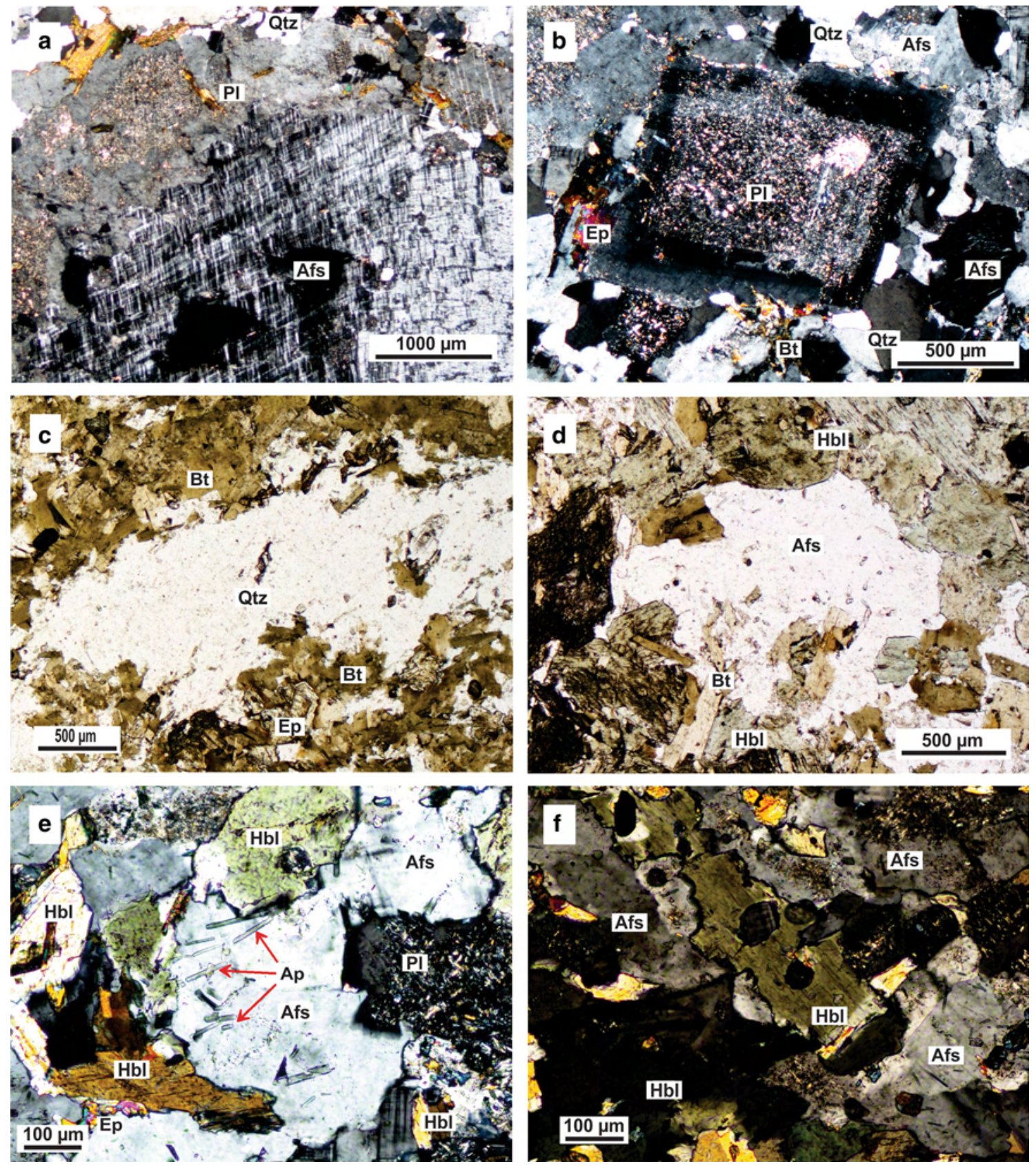

Figure 8. Petrographic features of MME: (a) Alkali feldspar grain mantled by plagioclase feldspar defining rapakivi texture; (b) Plagioclase grain showing sericitization and cellular zoning with resorbed surface; (c) Quartz grains being surrounded by bladed biotite in the granite, called as ocellar texture; (d) Alkali feldspar ocelli surrounded by hornblende in the MMEs; (e) Randomly oriented acicular apatites being formed in the alkali feldspar, and plagioclases are sericitized in the MMEs; (f) Hornblende poikilitically encloses microcline in the syn-plutonic mafic dyke.

mixing. Rapakivi texture (figure 8a), representing alkali feldspar surrounded by dendritic plagioclase indicates that high temperature plagioclase forms around the alkali feldspar due to the injection of mafic magma into host felsic magma. The dendritic growth of cellular plagioclase crystals depends on the thermal quenching that occur during the mixing of cool felsic magma with relatively hot mafic magma in a plutonic environment (Hibbard
1981; Barbarin 1990; Hibbard 1991; Jeen et al. 2002; Jayananda et al. 2014; Vernon 2016). Resorption textures in plagioclase are often interpreted as changes in plagioclase stability, caused due to mixing process (Hibbard 1981). Plagioclase in MMEs and syn-plutonic mafic dykes show resorbed surfaces (figures $11 \mathrm{~b}$ and $8 \mathrm{~b}$ ) along with calcic plagioclase overgrowth suggesting the occurrence of magma mixing. Pre-existing crystals of quartz and 

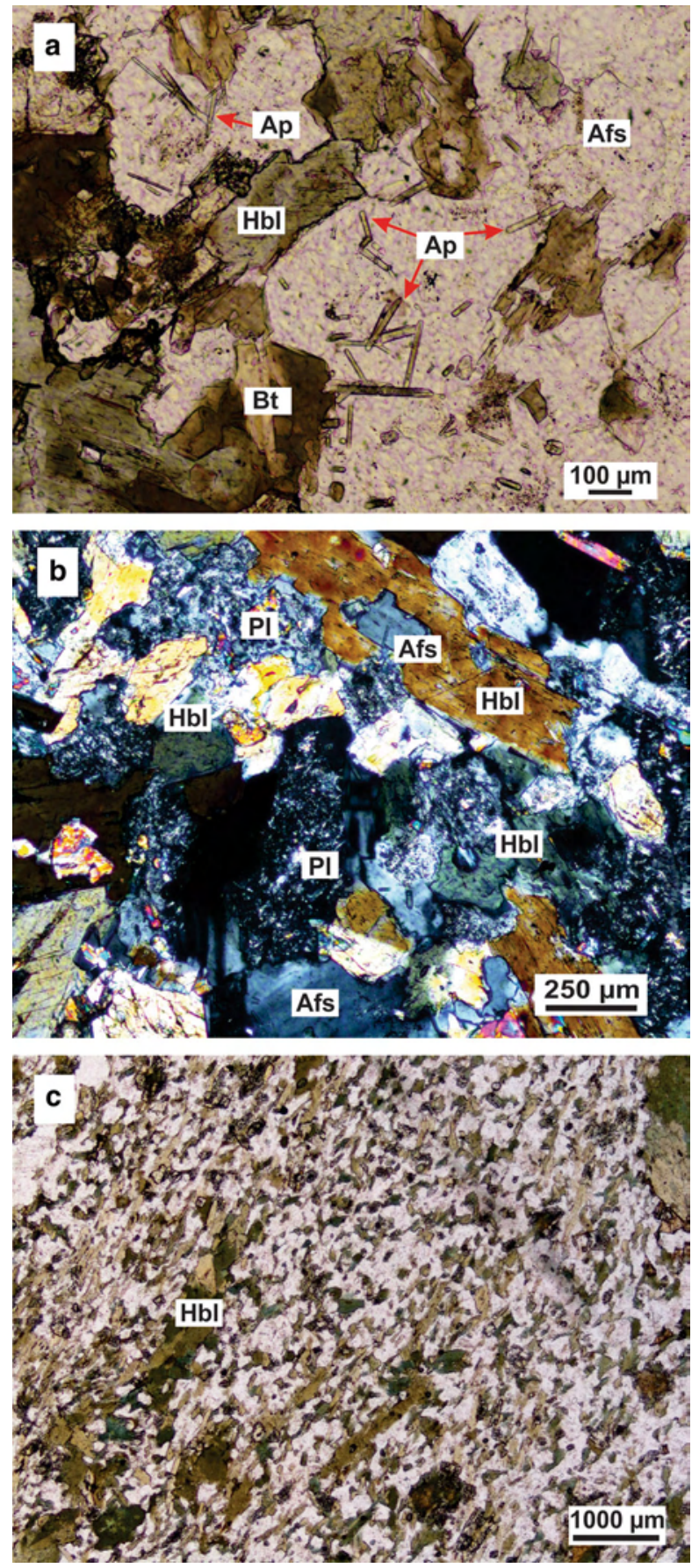

Figure 9. Petrographic features of syn-plutonic dykes (a) Acicular apatite formed in the alkali feldspar; (b) Hornblendes poikilitically encloses the early formed alkali feldspar and plagioclase sericitized in the MMEs and syn-plutonic mafic dyke, those alkali feldspars are incorporated from the crystallizing host granite; (c) Very fine grained syn-plutonic mafic dyke showing high nucleation rate and low growth rate of the essential minerals.

alkali feldspar (figure 8c and d) are dissolved due to the high temperature interaction of injected mafic magma into the host granite. Subsequent rapid crystallization of biotite and hornblende around the dissolute quartz and alkali feldspar results in ocelli textures (Hibbard 1991; Vernon 1991; Baxter and Feely 2002). Hornblende in the MMEs and syn-plutonic mafic dykes of Kanker granites poikilitically enclose the alkali feldspar (figures $8 \mathrm{f}$ and $9 \mathrm{~b}$ ), because the early formed alkali feldspar of the crystallizing host is injected into the mafic magma during magma mixing and mingling. Bladed biotite (figure 7c) is an evidence for physical restriction and rapid growth under supercooling environment, leading to magma mixing process (Hibbard 1981; Jeen et al. 2002). Acicular apatites are randomly crystallized in alkali feldspar of synplutonic mafic dykes and MMEs (figure 8e and 9a), form as a result of rapid growth in the quenched magma system (Hibbard 1991), and exemplifies the magma mixing process. The microstructures as outlined above, thus constrain the magma chamber processes in the Pithora region, Bastar Craton.

\subsection{Magma chamber processes and emplacement mechanism(s) of MMEs and syn-plutonic mafic dykes}

The interaction of coeval felsic and mafic magmas in the form of mixing and mingling depends on viscosity, crystallinity, temperature, rheology, composition, density, relative volume and the water content, and also it is a chaotic process, which depends largely on rheological behaviour of two magmas (Perugini et al. 2003; Perugini and Poli 2012). When the mafic magma intrudes into the crystallizing felsic host, the strong rheological contrast between the two magmas does not allow large scale interaction. The temperature of hotter mafic magma decrease rapidly, resulting in the heating of crystallizing felsic host. This process will narrow down rheological differences of two magmas leading to more physical interaction (Perugini et al. 2003). The formation of local hybridised enclaves delineates the occurrence of magma mixing process in magma chamber. Hybrid zone contains finegrained, ellipsoidal mafic as well as hybrid enclaves within the host granite suggesting the inflow of mafic magma into the mixing zone (figure 5a), indicating different pulses of mafic magmatic injection into the host granitic environment. Numerous hybrid enclaves were mechanically fragmented during the intrusion of crystallizing host granite (figure 5b). The slender-shaped melanocratic enclaves (figure $5 \mathrm{c}$ ) got diluted when interacting with the host granite, thus forming a local hybrid zone at tail region and forming schlieren structures. Intrusion of large syn-plutonic mafic dykes also 

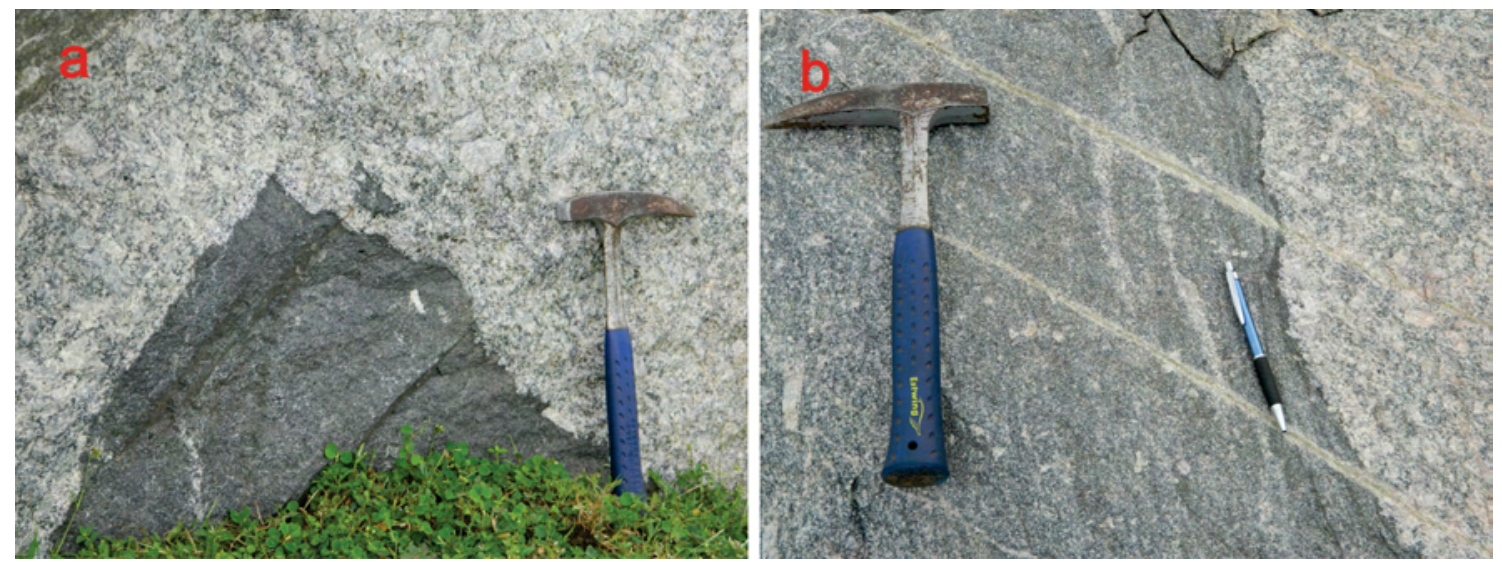

Figure 10. (a) Alkali feldspar phenocryst of the crystallizing host granite entering into MME, and some phenocrysts at the contact of MMEs and the host; (b) Syn-plutonic mafic dyke showing the chilled margin, and K-feldspar phenocryst along with later formed epidote vein cross-cutting the host granite and the syn-plutonic mafic dyke.

cause remelting of the crystallizing host, resulting in local mixing and hybridization (Jayananda et al. 2014). Such rocks are present at many places in Pithora region.

High temperature mafic magma entering into a relatively colder crystallizing felsic magma would be sufficient to raise the temperature of the host above the rheological locking point, which facilitate the convection adjacent to mafic injection. Such convection associated with felsic host facilitate to form the MME and syn-plutonic mafic dyke (Furman and Spera 1985). Finer grain size of the MME (figure 9c) is consistent with the higher nucleation rate and lower growth rate of constituent minerals in the mafic magma. Such condition occur when the hot mafic magma mixes with a relatively cold felsic magma, which eventually result in undercooling of the mafic magma leading to thermal equilibrium between both magmas (Jayananda et al. 2014). The mafic magma is more undercooled relative to the host, with respect to the liquidus temperature that induces rapid crystallization of minerals in the mafic magma (Vernon 1984; Choe and Jwa 2004). The MMEs are circular to elliptical in shape with sharp contact and chilled margin (figures $2 \mathrm{~b}, 3 \mathrm{~b}$ and 10b) indicating the intrusion of low viscous mafic magma into the crystallizing host granites. The observed field and microstructures of the granites from the Pithora region, thus, suggest that there was mixing and mingling of coexisting felsic and mafic magmas.

Many models have been proposed to understand the mechanism of mixing and mingling of felsic and mafic magmas in plutonic environment. Field and petrographic studies as outlined in the earlier sections demonstrate that the felsic and mafic magmas are coeval. Based on their petro-physical properties (e.g., rheology, composition, temperature, rate of crystallization and relative volumes of felsic and mafic magmas), Barbarin and Didier (1992) and Barbarin (2005) proposed a four-stage emplacement model (figure 12). First stage involves the intrusion of mafic magma before the crystallization of felsic magma, leading to the formation of homogenous hybrid magma under the influence of thermal and chemical exchange between the felsic and mafic magmas. In the second stage, mafic magma enters slightly later, when the felsic magma started crystallizing, leading to mechanical exchange between the coexisting magmas due to viscosity difference, blobs of mafic magma will form as MMEs in the felsic host magma. In the third stage, if magma introduced into the system when the felsic magma has partly crystallized (30-40\%), will allow only mingling, and produces composite or fragmented dyke. If the felsic magmas are partially crystallized, they are channelled into early fractures of nearly solid granite, and the intruding mafic magma will fill the available fractures and form disrupted dykes (Barbarin and Didier 1991). Finally, the mafic magma fills the fractures in the crystallized host granites and form syn-plutonic mafic dyke when the injection of mafic magma occurs at an advanced crystallisation stage (70-90\%) of felsic host.

The four-stage emplacement model of Barbarin and Didier (1992) fits well to describe textural variability and distribution of MME, as observed in the Pithora granite. We are able to substantiate this model (figure 12) with well-documented field observations. The homogenous hybrid rocks 


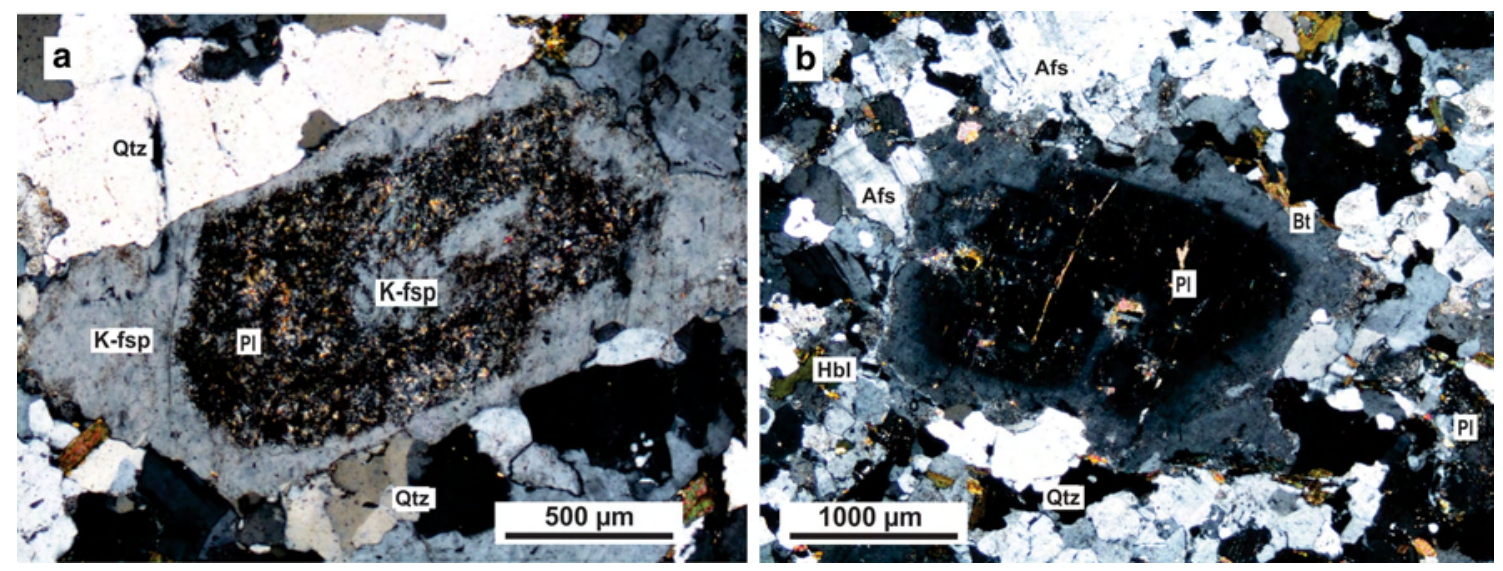

Figure 11. (a) Alkali feldspar mantled by dendritic plagioclase known as epitaxial crystallization or rapakivi texture; (b) Plagioclase grain with resorbed surface in host granite.

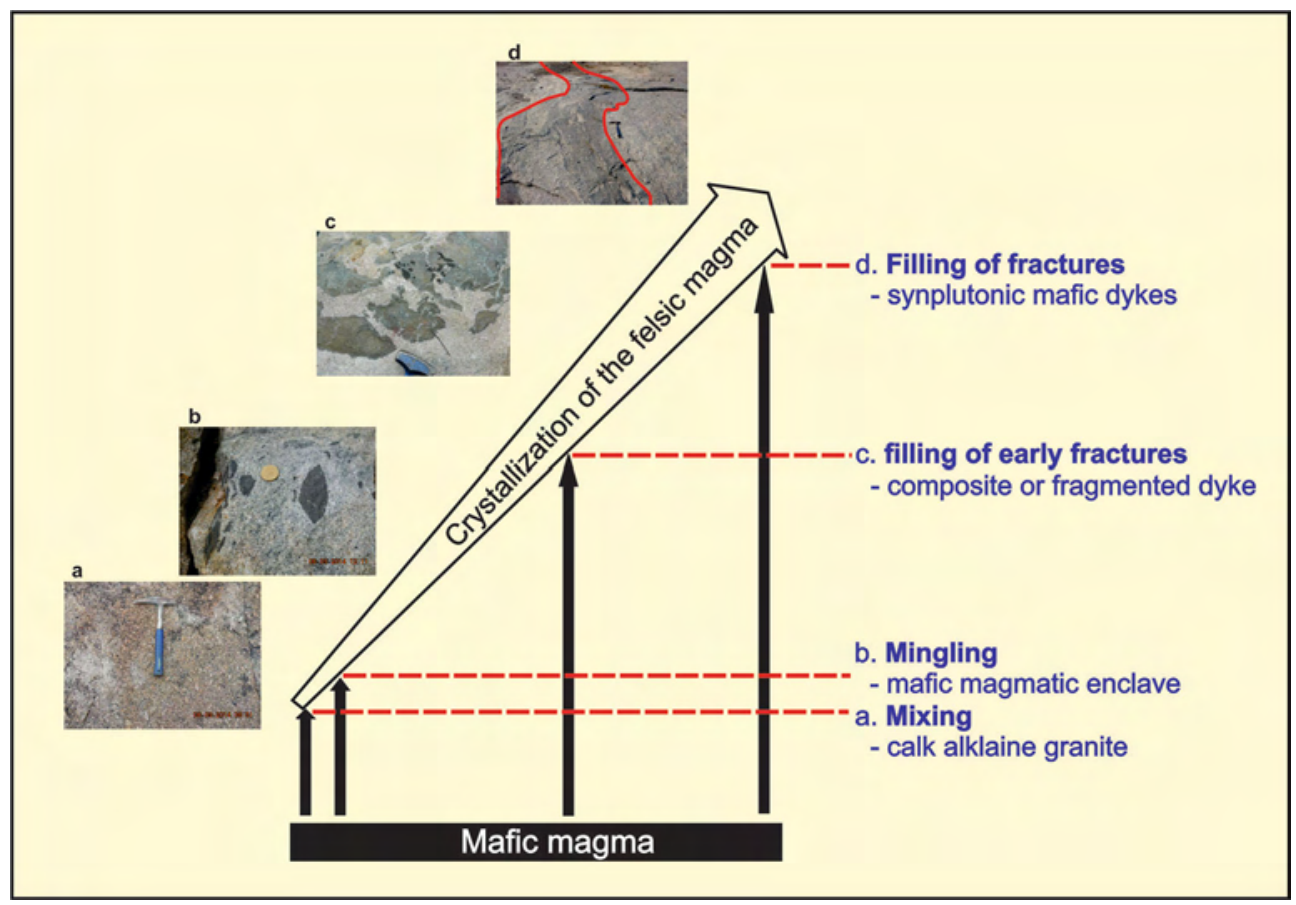

Figure 12. Sketch showing the different types of interaction, due to the injection of mafic magma into felsic magma at different crystallization levels (model after Barbarin and Didier 1992). (a) Mafic magma intrusion into felsic magma before crystallization leads to mixing process, forming the hybrid magma; (b) Mafic magma enters when felsic magma started to crystallize, will allow only mingling process and generation of mafic magmatic enclaves; (c) Mafic magma entering slightly later into the crystallizing host felsic magma, will emplace as fragmented dyke; (d) Mafic magma intrusion into the significantly crystallized felsic magma, will fill the fractures and occur as syn-plutonic mafic dyke.

suggest that there was complete mixing of felsic and mafic magmas which occurred at deeper levels of the magma chamber (figures 5 and 12a) in the first stage of intrusion with low degree of crystallinity. Hybrid enclaves (figure 5) occur when the heat and hydrous volatiles released from the intruding MMEs, resulted in rheological behaviour of the crystallising host in a narrow range (Blundy and Sparks 1992). The homogenous hybrid rocks suggest that there was complete mixing of mafic and felsic magmas with low degree of crystallinity (Barbarin and Didier 1992; Jayananda et al. 2014). These hybrid rocks are formed by chemical interaction during the mixing of felsic and mafic magmas. MMEs of Pithora region (figures 2, 3 and $12 \mathrm{~b})$ are scattered throughout the pluton due to the convection, flow velocity and density contrast. Irregularities in the magma chamber wall can also reduce the magma velocity and cause abrupt changes in the magmatic flow (Arvin et al. 2004), 
which results in emplacement of randomly oriented MMEs in the second stage of intrusion. Disrupted syn-plutonic mafic dykes are formed in the third stage of intrusion in the crystallized granitoids (figures $3 \mathrm{e}, 4 \mathrm{c}$ and $12 \mathrm{c}$ ). In the final stage, mafic magma intruded to fill the fractures in crystallised felsic host, forming the syn-plutonic mafic dykes (figures 4 and 12d).

\section{Conclusions}

- Field evidences show injection of mafic magma into crystallizing host with different stages of interaction through mixing, mingling and hybridization.

- Petrographic evidences such as disequilibrium assemblages, resorption, rapakivi, poikilitic, alkali feldspar and quartz ocelli textures suggest the interaction of felsic and mafic magmas, and their coeval nature.

- Our studies suggest that textural variation and heterogeneous nature of Kanker granites in the Pithora region of Bastar Craton is due to the interaction of mafic and felsic magmas at different stages of crystallisation of the latter.

\section{Acknowledgements}

Director, CSIR-NGRI is thanked for permitting to publish this work. This work is an outcome of the INDEX WP 2.3 (MRM), and forms part of the $\mathrm{PhD}$ work of the first author. We thank the two anonymous reviewers for their critical comments that have helped to significantly improve the previous version of manuscript.

\section{References}

Arvin M, Dargahi S and Babaei A A 2004 Mafic microgranular enclave swarms in the Chenar granitoid stock, NW of Kerman, Iran: Evidence for magma mingling; J. Asian Earth Sci. 24 105-113.

Bandyopadhyay B, Roy A and Huin A 1994 Structure and tectonics of a part of the central Indian shield; Geol. Soc. India Memoirs, pp. 433-468.

Barbarin B 1988 Field evidence for sucessive mixing and mingling between the Piolard Diorite and the SaintJulien-la-Vetre Monzogranite; Canadian J. Earth Sci. 25 49-59.

Barbarin B 1990 Plagioclase xenocrysts and mafic magmatic enclave in some granitoids of the Sierranevada Bhatholith, California; J. Geophys. Res. 95 17,747-17,756.

Barbarin B 2005 Mafic magmatic enclaves and mafic rocks associated with some granitoids of the central Sierra
Nevada batholith, California: Nature, origin, and relations with the hosts; Lithos 80 155-177.

Barbarin B and Didier J 1991 Review of the main hypothesis proposed for the genesis and evolution of mafic microgranular enclaves; In: Enclaves and Granite Petrology, Dev. Petrol. 13 367-373.

Barbarin B and Didier J 1992 Genesis and evolution of mafic microgranular enclaves through various types of interaction between coexisting felsic and mafic magmas; Geol. Soc. Am. Spec. Papers 272 145-153.

Baxter S and Feely M 2002 Magma mixing and mingling textures in granitoids: Examples from the Galway Granite, Connemara, Ireland; Mineral. Petrol. 76(1) 63-74.

Blundy J D and Sparks R S J 1992 Petrogenesis of mafic inclusions in granitoids of the Adamello Massif, Italy; J. Petrol. 33(5) 1039-1104.

Chatterjee A 1970 Structure, tectonics and metamorphism in a part of south Bastar, MP; Quat. J. Geol. Min. Met. Soc. India 42 75-95.

Choe W H and Jwa Y J 2004 Petrological and geochemical evidences for magma mixing in the Palgongsan Pluton; Geosci. J. 8 343-354.

Crookshank H (1938) The western margin of the Eastern Ghats in southern Jeypore. Rec. Geol. Surv. India, 73(3) 398-434.

Didier J and Barbarin B 1991 The different types of enclaves in granites - Nomenclature; Enclaves and Granite Petrology, Dev. Petrol., Elsevier, Amsterdam 13 19-23.

Frost T P and Mahood G A 1987 Field, chemical, and physical constraints on mafic-felsic magma interaction in the Lamarck granodiorite, Sierra Nevada, California (USA); Geol. Soc. Am. Bull. 99 272-291.

Furman T and Spera F J 1985 Co-mingling of acid and basic magma with implications for the origin of mafic I-type xenoliths: Field and petrochemical relations of an unusual dike complex at eagle lake, Sequoia National Park, California, USA; J. Volcan. Geother. Res. 24 151-178.

Ghosh P 1941 The charnockite series of Bastar state and western Jeypore; Rec. Geol. Surv. India 75 1-55.

Ghosh J G 20043.56 Ga tonalite in the central part of the Bastar craton, India: Oldest Indian date; J. Asian Earth Sci. 23 359-364.

Hibbard M 1981 The magma mixing origin of mantled feldspars; Contrib. Mineral. Petrol. 76 158-170.

Hibbard M J 1991 Textural anatomy of twelve magma-mixed granitoid systems; In: Enclaves and Granite Petrology, Dev. Petrol., Elsevier, Amsterdam 32 431-444.

Jayananda M, Gireesh R, Sekhamo K-U and Miyazaki T 2014 Coeval felsic and mafic magmas in neoarchean calcalkaline magmatic arcs, Dharwar craton, southern India: Field and petrographic evidence from mafic to hybrid magmatic enclaves and synplutonic mafic dykes; J. Geol. Soc. India 84 5-28.

Jayananda M, Miyazaki T, Gireesh R V, Mahesha N and Kano T 2009 Synplutonic mafic dykes from late archaean granitoids in the Eastern Dharwar Craton, southern India; J. Geol. Soc. India 73 117-130.

Jeen M J, Kim J S and Lee J D 2002 Study on the origin of rapakivi texture in Bangeojin granite; J. Petrol. Soc. Korea 11 30-48.

Kumar S 2010 Mafic to hybrid microgranular enclaves in the Ladakh batholith, northwest Himalaya: Implications 
on calc-alkaline magma chamber processes; J. Geol. Soc. India 76 5-25.

Kumar S, Bora S and Sharma U K 2016 Geological appraisal of Ladakh and Tirit granitoids in the Indus-Shyok Suture Zones of northwest Himalaya, India; J. Geol. Soc. India $87737-746$.

Kumar S, Pieru T, Rino V and Lyngdoh B C 2005 Microgranular enclaves in neoproterozoic granitoids of south Khasi Hills, Meghalaya Plateau, northeast India: Field evidence of interacting coeval mafic and felsic magmas; J. Geol. Soc. India 65 629-633.

Kumar S and Rino V 2006 Mineralogy and geochemistry of microgranular enclaves in Palaeoproterozoic Malanjkhand granitoids, central India: Evidence of magma mixing, mingling, and chemical equilibration; Contrib. Mineral. Petrol. 152 591-609.

Kumar S, Rino V and Pal A 2004 Field evidence of magma mixing from microgranular enclaves hosted in Palaeoproterozoic Malanjkhand granitoids, central India; Gondwana Res. 7 539-548.

Manikyamba C, Santosh M, Kumar B C, Rambabu S, Tang L, Saha A, Khelen A C, Ganguly S, Singh T D and Rao D S 2016 Zircon U-Pb geochronology, Lu-Hf isotope systematics, and geochemistry of bimodal volcanic rocks and associated granitoids from Kotri Belt, Central India: Implications for NeoarcheanPaleoproterozoic crustal growth; Gondwana Res. 38 313-333.

Martin H, Moyen J F and Rapp R 2009 The sanukitoid series: Magmatism at the Archaean-Proterozoic transition; Geol. Soc. Am. Spec. Papers 472 15-33.

Mishra V, Singh P and Dutta N 1988 Stratigraphy, structure and metamorphic history of Bastar craton; Rec. Geol. Surv. India 1178.

Mohanty S P 2015 Palaeoproterozoic supracrustals of the Bastar Craton: Dongargarh supergroup and sausar group; Geol. Soc. London Memoirs 43(1) 151-164.

Moyen J F 2011 The composite Archaean grey gneisses: Petrological significance, and evidence for a non-unique tectonic setting for Archaean crustal growth; Lithos 123(1) 21-36.

Moyen J F, Champion D and Smithies R H 2010 The geochemistry of Archaean plagioclase-rich granites as a marker of source enrichment and depth of melting; Geol. Soc. Am. Spec. Papers 472 35-50.

Pandey D, Krishnamurthy P and Gupta J 1993 Sm-Nd and $\mathrm{Pb}-\mathrm{Pb}$ geochronology of the Dongargarh granites, Central India: Implications to petrogenesis; 6th NSMS Dehradun Preprint volume, pp. 503-505.
Pandit D and Panigrahi M K 2012 Comparative petrogenesis and tectonics of Paleoproterozoic Malanjkhand and Dongargarh granitoids, central India; J. Asian Earth Sci. 50 14-26.

Perugini D and Poli G 2012 The mixing of magmas in plutonic and volcanic environments: Analogies and differences; Lithos 153 261-277.

Perugini D, Poli G, Christofides G and Eleftheriadis G 2003 Magma mixing in the Sithonia Plutonic Complex, Greece: Evidence from mafic microgranular enclaves; Mineral. Petrol. 78 173-200.

Prabhakar B C, Jayananda M, Shareef M and Kano T 2009 Synplutonic mafic injections into crystallizing granite pluton from gurgunta area, northern part of Eastern Dharwar Craton: Implications for magma chamber processes. J. Geol. Soc. India $\mathbf{7 4}$ 171-188.

Ramachandra H, Roy A, Mishra V and Dutta N 2001 A critical review of the tectonothermal evolution of the Bastar Craton; J. Geol. Soc. India Spec. Publ. 55 161-180.

Ramakrishnan M and Vaidyanathan R 2008 Geology of India; Geol. Soc. India 1, 556p.

Renjith M, Charan S, Subbarao D, Babu E and Rajashekhar V 2014 Grain to outcrop-scale frozen moments of dynamic magma mixing in the syenite magma chamber, Yelagiri Alkaline Complex, South India; Geosci. Frontiers $\mathbf{5}$ 801-820.

Sarkar A, Sarkar G, Paul D and Mitra N 1990 Precambrian geochronology of the central Indian shield - a review; Geol. Surv. India, Spec. Publ. 28 353-382.

Sarkar G, Corfu F, Paul D, McNaughton N, Gupta S and Bishui P 1993 Early Archean crust in Bastar Craton, central India - a geochemical and isotopic study; Precamb. Res. 62 127-137.

Sarkar S, Gopalan K and Trivedi J 1981 New data on the geochronology of the Precambrians of Bhandara-Drug, central India; Indian J. Earth Sci. 8(2) 131-151.

Vernon R H 1991 Interpretaton of microstructure of microgranitoid enclaves; In: Enclaves and Granite Petrology, Dev. Petrol, Elsevier, Amsterdam 13 277-291.

Vernon R H 1984 Microgranitoid enclaves in granites - Globules of hybrid magma quenched in a plutonic environment; Nature 309 438-439.

Vernon R H, Etheridge M A and Wall V J 1988 Shape and microstructure of microgranitoid enclaves: Indicators of magma mingling and flow; Lithos 22 1-11.

Vernon R H 2016 Rapakivi granite problems: Plagioclase mantles and ovoid megacrysts; Austr. J. Earth Sci. 63(6) $675-700$. 